Of particular concern, from the practical viewpoint, is the effect of dormant lime sulfur and copper sulphate sprays upon the pycnospores lodged in the pycnidia and destined to function after petal-fall.

Wallace ${ }^{1}$ in his official reports and Douglas ${ }^{2}$ have repeatedly published the statement that a very strong solution of lime sulfur, applied before the buds begin to swell, perfectly controlled this disease and that the summer sprays, consequently, were unnecessary. The writer disagrees with their views, but has discovered from field and laboratory experiments and obervations, the scientific explanation of partial control by the dormant sprays applied late.

The infectious surface of an apple blotch canker in the first season of its functional activity consists of two distinct portions: first, that portion which develops from a single infection, becoming apparent in late summer and ceasing its active growth upon the appearance of cold weather; second, that porton which advances from the initial canker the following spring, approximately two weeks after the buds burst open, and which becomes dotted with pycnidia, with mature pycnospores, simultaneously with the advance of the canker. The first portion is the initial canker and bears pseudo-pycnidia. The contents of the pseudo-pycnidia are completely or partially differentiated into spores by the time it is customary to apply the dormant spray. Furthermore, the epidermal covering over the pycnidia is ruptured, exposing the pycnidial wall. The season's young fruits and new growth are, therefore, subject to two distinct sources of infection from the young blotch cankers.

A dormant spray of lime sulfur applied as the buds begin to swell actually kills the spores and sporidal layer within the differentiated pseudo-pycnidia but has absolutely no

1 Wallace, F. N., 9th Annual Report Indiana State Entomologist, 1915-16, pp. 51, 54.

2 Douglas, B. W., "War and the Fruit Grower," Country Gentleman, Septemiber 14, 1918; "Fruit Diseases of 1919," Country Gentleman, April 17, 1920. effect upon the mycelium of the organism ramifying throughout the cortical tissue beneath. The toxic effect upon the spores is very striking after the first rain following the dormant spray. Dilutions of lime sulfur of 1-3, 1-5, 1-6, and 1-8, were given their trial and all were similarly toxic to the spores in the pycnidia, but it appeared that dilutions somewhat stronger than 1-8 were more effcient. A dilution of copper sulphate (1-6) produces similar toxic effects. Scalecide produces none at all.

As was mentioned above, a new infectious area advances from the initial canker in the spring. It follows, therefore, that the dormant spray exercises but very little control upon the season's infection of the young apples and new growth.

UNIVERSITY OF ILLINOIS

$$
\text { E. F. GubA }
$$

\section{CROWS AND STARLINGS}

To the Editor of ScIence: Last fall at Devon, Pennsylvania, a man shooting blackbirds also wounded a starling, which fell on the grass and which he could not find. Shortly afterwards several crows were seen diving at something in the grass and then lighting and running through the grass after it. Upon his going towards them to see what they were doing, they all flew away, one of them carrying the starling in its bill, and landed on the walk in a neighboring place, where the crows gathered round the starling and proceeded to peck at it. He followed them and scared them, and the crows flew away, abandoning the starling, which was nearly dead.

I have never before known of crows carrying off as large a bird as a starling, though I have seen one carrying off from the nest a young robin nearly ready to fly, and of course they kill many young robins and other young birds of smaller size.

\section{F. R. WELSH}

THE SYNCHRONAL FLASHING OF FIREFLIES

DURING a trip in Siam, a distinct flashing of fireflies in unison was observed. The observa- 
tions were made during the evenings of June 5 and 6, 1920, from a house boat on the Tachin River, in the district of Sarm Prarm, Nakorn Chaisri, Siam. A distinct flashing of dark and light was observed. A whole tree of flies would flash all together at regular intervals of, by count with a watch, between 105 and 109 flashes a minute.

Frequently entire trees filled with fireflies are observed at the College of Agriculture, Los Baños, Laguna, Philippine Islands and it was at first thought by the writer that an extremely rapid flashing in unison took place. After, however, observing the distinct flashing in unison of the fireflies in Siam it can be stated with certainty that no such synchronal flashing took place at Los Baños.

Determinations made by $\mathrm{H}$. E. Woodworth, of the College of Agriculture, Los Baños, on fireflies from Siam, showed these flies to be of the genus Calaphotia. Professor Woodworth states that the firefly at Los Baños is of the same genus, but of a different species. Neither species has been determined.

Otтo A. Reinking

College of Agriculture, Los Baños, PhILIPPINe Islands

\section{FRANZ STEINDACHNER}

To the Editor of Science: I read with much interest the article of Dr. Jordan on Franz Steindachner. I had the great pleasure of visiting Dr. Steindachner twice; once in 1878 and again twenty years later in 1898. $\mathrm{He}$ was living in the simple way described by Dr. Jordan on the occasion of both my visits. His maiden sister at that time, however, was living and was keeping house for him in a perfectly simple manner.

I do not wish to speak of Steindachner's great achievements in ichthyology. I want to add my little tribute to his value as a friend. The simplicity of his life, the wonderful clarity of his character and his devotion to his friends make him almost as rerenowned as his achievements in the investigation of fishes. At the time of my last visit he had achieved the full distinction of head superintendent of the Royal Imperial $\mathrm{Mu}$ - seums. He enjoyed to a remarkable degree the confidence of the Emperor Franz Josef. Through a special permit from the imperial palace I was permitted under his guidance to visit the castle with all of its belongings in which the heir to the throne was murdered a few years before.

I was particularly struck with the amity and friendship shown him by the people with whom he worked. As a host he was the essence of geniality and at the same time of simplicity. I carried letters to him on my first visit from friends in Harvard who knew him when he was a resident of Cambridge. He had a great admiration for this country and he numbered many personal and professional friends on this side of the water. While war broke up all political and many social relations with Germany and Austria, I feel quite certain all the personal friends of $\mathrm{Dr}$. Steindachner on this side remained loyal to him through his later years of sorrow and distress, due to the exigencies of the war. The grief for him as a friend is more poignant than the regret of his loss to science.

H. W. Wrley.

\section{SCIENTIFIC BOOKS}

Chemische Krystallographie. By P. Groth. Leipzig, Wilhelm Engelmann. Vol. I., 1906; II., 1908; III., 1911; IV., 1917; V., 1919. 4,443 pages, with 3,342 figures; 8vo, cloth.

All persons interested in crystallized substances will be delighted to know that this monumental work, in the preparation of which Professor Groth spent several decades, has been finally completed. Notices of the publication of the first three volumes have already appeared in ScIence. ${ }^{1}$ Vol. IV. was issued in 1917 and Vol. V. late in 1919.

According to the original plan it was thought that all the available material could be conveniently published in four volumes; the first two to be devoted to inorganic, and the last two volumes to organic compounds. The aromatic organic compounds, however, proved to be much more numerous than had been

1 Vol. XXV., 143-144; Vol. XXVIII., 843; Vol. XXXIII., 253. 